\title{
HISTORIE VÝUKY LÉKAŘSKÉ ELEKTRONIKY NA ELEKTROTECHNICKÉ FAKULTĚ VYSOKÉHO UČENÍ TECHNICKÉHO V BRNĚ
}

\author{
MILAN CHMELA ̌̌
}

\section{HISTORY OF TEACHING MEDICAL ELECTRONICS AT THE FACULTY OF ELECTRICAL ENGINEERING OF THE BRNO UNIVERSITY OF TECHNOLOGY}

The Department of Medical Electronics (now Department of Biomedical Engineering) at the Faculty of Electrical Engineering of the Brno University of Technology was the first of its kind in Czechoslovakia. It was established in 1967, importantly contributed to the development of medical electronics, and many of its graduates became important specialists. This contribution follows the history of medical electronics with focus on the development of the abovementioned department. Added are brief biographies of heads of this department from 1967 until the present.

Keywords: Brno University of Technology - Faculty of Electrical Engineering - Department of Medical Electronics

DOI: $10.14712 / 23365730.2018 .37$

Lékařská elektronika je obor, který hluboce zasahuje do osudů lidí. Může jim pomoci při obnově zdraví, v řadě př́ípadů se podílí i na záchraně jejich životů. Tento obor je velice široký, protože do něj spadá oblast elektroniky, patř́ sem i strojní obory a materiálové inženýrství a v neposlední řadě se zde jedná o vazbu na nové poznatky v oblasti medicíny. Podívejme se na to, jak výuka lékařské elektroniky v dřívějších letech na Elektrotechnické fakultě probíhala.

\section{Historický přehled oboru}

Moderní historie současné a samostatné fakulty se začala psát v roce 1959, kdy byla zákonem zřízena Fakulta elektrotechnická Vysokého učení technického (VUT) v Brně, která vznikla rozdělením Fakulty energetické na Fakultu strojní a Fakultu elektrotechnickou. Podle studijního programu této fakulty z akademického roku 1959/1960 zde existovalo pět kateder, a to Katedra elektrotechnických nauk, Katedra elektrických strojů a zařízení, Katedra elektroenergetiky, Katedra radiotechniky (její součástí byla i automatizace a měření) a Katedra linkové techniky.

V letech 1959 až 1966 Katedra linkové techniky, Katedra radiotechniky a později Katedra automatizace a měricí techniky (která se vyčlenila z Katedry radiotechniky) stř́ídavě 
zajišt'ovaly předmět zabývající se elektronikou v lékařství, u kterého rozsah kolísal mezi dvěma až třemi hodinami přednášek týdně. Jeho součástí byla i cvičení a byl zakončen zkouškou. S ohledem na počet hodin výuky to byl předmět pouze přehledový. K velmi významné změně došlo okolo roku 1967 . V tehdejší době došlo $\mathrm{k}$ jednání mezi koncernovým podnikem Chirana a Elektrotechnickou fakultou VUT v Brně, kterou z pověření děkana fakulty zastupoval docent Vratislav Vrána. Koncernový podnik Chirana měl ředitelství ve Staré Turé, jeho výzkumný ústav, který vyvíjel pro koncern př́stroje, byl situován v Brně a jeho výrobní podniky se nacházely po celé republice. Chirana se tenkrát zavázala $\mathrm{k}$ tomu, že bude nabízet práci absolventům Elektrotechnické fakulty a celé toto jednání vedlo k tomu, že na Elektrotechnické fakultě vznikla ke dni 1.2. 1967 samostatná Katedra lékařské elektroniky. Ta byla $\mathrm{v}$ té době jediná v celé ČSSR. Jejím vedoucím byl ustanoven Vratislav Vrána, který prripravil veškeré podklady potřebné pro zahájení výuky. Hned v roce 1967 odjel učit na jeden rok na Military Technical College do Káhiry a v té době jej jako pověřený vedoucí zastupoval Milan Chmelař. Ve studijním programu Elektrotechnické fakulty z roku 1967/1968 existovaly na oboru technická kybernetika, zaměření měřicí a řídící technika, dvě skupiny volitelných předmětů. První skupina se lékařské elektroniky netýkala; do druhé skupiny patřily předměty základy lékařství, elektronické př́stroje v lékařství I, elektronické př́istroje v lékařství II, rentgenové př́stroje, vysokofrekvenční a ultrazvuková technika $\mathrm{v}$ lékařství a ročníkový projekt.

Se zajištěním výuky (hlavně laboratorní) byly problémy. Chybělo vybavení i prostory, řadu věcí bylo nutno řešit po vzájemné dohodě s jinými katedrami a samo umístění Katedry lékařské elektroniky bylo značně provizorní. Nebylo se čemu divit. Fakulta měla sama velké problémy s prostorami a neměla z čeho dávat. Na straně druhé to vše vyvažovalo nadšení lidí, kteří zde pracovali, čemuž odpovídaly také dosažené výsledky.

Po založení Katedry lékařské elektroniky, úzce specializované na obor aplikované radioelektroniky, měřicích metod a počítačů v lékařství, se museli její pracovníci zabývat obsahovou náplní přednášek, sestavením učebních osnov v návaznosti na existující učební programy kateder, investičním zajiššením základních př́istrojů pro laboratoře a zařízení pro dílnu, prostorovou dislokací pro laboratoře katedry, pracovny docentů a asistentů a tvorbou skript. Skripta, která na katedře postupem času vznikala, byla používána i jinými vysokými školami, jež později zahájily výuku v př́buzných oborech. $V$ tomto směru to byla od jejich autorů vlastně průkopnická práce.

Z investic katedra získala sumárně částku 553000 Kčs. Vzhledem k tomu, že při založení Katedry lékařské elektroniky fakulta žádné př́strojové vybavení pro tuto specializovanou výuku neměla, nebylo to mnoho. Je však nutno si uvědomit, že srovnávat uvedenou částku s hodnotou koruny v roce 2017 není možné (nyní stejná částka znamená výrazně méně).

Původní budova, ve které byla Katedra lékařské elektroniky, nepatřila VUT v Brně a navíc byla určena $\mathrm{k}$ demolici. Na Žerotínově náměstí se měla stavět budova městského výboru KSČ, a tak bylo jen otázkou času, kdy bude muset nově vzniklá katedra tento prostor vyklidit. I preses tyto problémy bylo velmi potěšitelné, že na této nově zřízené katedře končilo studium Elektrotechnické fakulty okolo čtyřiceti studentů ročně. Zájem mezi studenty tedy byl.

Problémy s dislokací katedry byly zásadní a trvaly desítky let. Pracoviště se několikrát stěhovalo a celá řada $\mathrm{z}$ lokací byla provizoria. Katedra byla dislokována na několika místech v Brně, nejprve zcela odděleně od dalších fakultních pracovišt'. Postupně vystř́ídala několik adres - od roku 1967 Žerotínovo náměstí č. 7, od roku 1974 Purkyňova 95B 
(montovaná nezděná budova, tzv. Tesco barák), od roku 1991sídlila v ulici Technická, pod výškovou budovou Fakulty strojní v místě nynějšího Technologického parku (dva Tesco baráky, prostorově čtyřnásobek toho, co bylo předtím - v současné době již neexistují); dále Purkyňova 79A (první zděná a solidní budova, datum nastěhování se nepodařilo dohledat), od roku 1997 Purkyňova 118 (př́stavba k rekonstruované budově po firmě MEOPTA, poprvé společně s některými dalšími ústavy fakulty), od roku 2004 Kolejní 4 (rekonstruovaná budova po bývalé menze VUT sdílená s Fakultou podnikatelskou), od roku 2013 Technická 12 (nově postavená budova Fakulty elektrotechniky a komunikačních technologií, první umístění všech pracovišt' fakulty v jednom místě).

Výraznější posun z hlediska prostorových možností znamenal přesun na Kolejní 4. Zde již byl dostatek prostoru jak pro kanceláře zaměstnanců a doktorandů, tak i pro výuku a zejména pro laboratorní výuku. $\mathrm{K}$ dalšímu výraznému zlepšení došlo přestěhováním do nové budovy Fakulty elektrotechniky a komunikačních technologií na Technické 12. $\mathrm{V}$ posledních letech totiž došlo ze strany VUT $\mathrm{k}$ velké podpoře výstavby nové budovy Fakulty elektrotechniky a komunikačních technologií. Poprvé v historii tak mohl od roku 2013 Ústav biomedicínského inženýrství plně využít potenciálu umístění všech pracovišt' fakulty se špičkovým vybavením na jednom místě.

Při svém zřízení v roce 1967 měla katedra celkem šest zaměstnanců, z toho čtyři učitele. K tomu je ovšem nutno připočíst řadu externích spolupracovníků, kteří se na zajištění výuky podíleli. V roce 1970 to již bylo celkem jedenáct zaměstnanců (sedm učitelů a čtyři ne-učitelé). V roce 1971 se tento počet ještě zvýšil a to na šest učitelů, osm neučitelských pracovníků, $\mathrm{z}$ toho tři byli výzkumníci. $V$ té době měla katedra i celkem slušně vybavenou dílnu, ve které se nacházel malý soustruh, stojanová vrtačka, bruska, ohýbačka plechu, pákové nůžky na plech, bodová svářečka, plynová svářecí souprava a kompletní vybavení pro výrobu plošných spojů. Byly zde realizovány nejen různé př́ipravky pro laboratorní cvičení, ale i výsledky výzkumné činnosti katedry. S postupem let počet zaměstnanců katedry vzrůstal. Laboratoře ovšem pořád zůstávaly omezeny prostorem.

V akademickém roce 1971/1972 byly v nabídce předměty: základy lékařství, elektrické vlastnosti organismů, použití počítačů v lékařské elektronice, elektronické lékařské př́istroje, ultrazvuková technika v lékařství, záření v lékařství, biotelemetrie a navrhování lékařských př́istrojů (ročníkový projekt). V akademickém roce 1974/1975 došlo ke změně. Přibyly předměty vysokofrekvenční technika a lékařská kybernetika. Poté až do akademického roku 1979/1980 zůstaly tyto předměty zachovány. K další změně došlo v akademickém roce 1980/1981, v němž začala Katedra lékařské elektroniky na fakultě zajišt'ovat pro všechny elektrotechnické obory výuku předmětu životní prostředí. Akademický rok 1981/1982 byl z hlediska výuky na celé Elektrotechnické fakultě přechodný. Na základě rozhodnutí vědecké rady fakulty došlo totiž ke změně učebních plánů, které byly přizpůsobeny západoevropským univerzitním zvyklostem, a tak se dočasně učilo současně ve dvou ročnících. V akademickém roce 1982/1983 zajištovala Katedra lékařské elektroniky předměty biologické systémy, lékařská přístrojová technika I a II, zobrazovací systémy v lékařství, zpracování biologických signálů, teorie diagnostiky systémů a ekonomika a řízení. U všech studijních oborů zajišstovala katedra výuku předmětu životní prostředí. Další změna pak přišla v akademickém roce 1986/1987, kdy se objevil navíc předmět technicko-právní problémy.

Dne 14. 5. 1990 došlo ke změně názvu Katedry lékařské elektroniky na Katedru biomedicínského inženýrství. I když to z vnějšího pohledu vypadá na pouhou formalitu, nebylo tomu 
tak. Změna názvu souvisela s celosvětovým rozvojem techniky pro zdravotnictví a nový název lépe vystihoval celou šíri problematiky, která do oblasti př́strojů a zařízení pro zdravotnictví patří. V roce 1997 došlo na FEKT VUT k přejmenování kateder na ústavy, takže současný název bývalé Katedry lékařské elektroniky je Ústav biomedicínského inženýrství.

Významné změny v rozsahu studia se datují od roku 1999. Tehdy vznikl magisterský obor biomedicínské a ekologické inženýrství, v roce 2007 pak bakalářský obor biomedicínská technika a bioinformatika (mezioborové studium ve spolupráci s Lékařskou fakultou Masarykovy univerzity). V roce 2010 byl otevřen navazující magisterský obor biomedicínské inženýrství a bioinformatika. O tyto nové obory byl velký zájem (podle údajů studijního oddělení děkanátu FEKT VUT v Brně), zejména pak mezi dívkami, jejichž počet v řadách studentů významně vzrostl až na současných $50 \%$ (tento fakt vynikne zvláště v kontrastu se $4 \%$ dívek studujících na elektrotechnických oborech fakulty).

V současné době (tedy k roku 2017) nabízí Ústav biomedicínského inženýrství následující studijní programy a obory: biomedicínská technika a bioinformatika (trríletý bakalářský studijní program a stejnojmenný obor), zaměření biomedicínská elektronika (v rámci tříletých bakalářských oborů elektronika a sdělovací technika, automatizační a měřicí technika, mikroelektronika a technologie v programu elektrotechnika, elektronika, komunikační a ř́́dicí technika), biomedicínské a ekologické inženýrství (dvouletý navazující studijní obor v rámci programu elektrotechnika, elektronika, komunikační a řídicí technika) a biomedicínské inženýrství a bioinformatika (dvouletý navazující magisterský studijní program a stejnojmenný obor).

Ústav biomedicínského inženýrství má celkem šestnáct špičkově vybavených laboratoří. Personální obsazení ústavu tvořili v roce 2017 dva profesoři, pět docentů, dvanáct odborných asistentů, jeden asistent, jeden vědecký pracovník, devět technických pracovníků, tři administrativní pracovníci, celkem tedy třicet tři zaměstnanců (dvacet jedna mužů a dvanáct žen). Dále na ústavu působí devět externích spolupracovníků (z toho pět docentů a jeden profesor), dvacet tři doktorandi v prezenční formě studia a třicet jeden doktorand v kombinované formě.

\section{Spolupráce s průmyslem a zdravotnictvím}

Katedra lékařské elektroniky vždy spolupracovala s průmyslovými podniky a zdravotnickými pracovišti. V počátcích katedry se jednalo zejména o spolupráci s koncernovým podnikem Chirana, včetně vývojových pracovišt' Chirana Stará Turá a Chirana Brno, kde byly zajištěny stáže studentů.

Dále probíhala spolupráce s podnikem Tesla Valašské Meziříčí a dalšími. Dlouhá léta trvala spolupráce s firmou Brněnské veletrhy a výstavy (současný název je Veletrhy Brno, a.s.) v hodnotící komisi na mezinárodním veletrhu zdravotnické techniky MEFA v Brně. Nynější Ústav biomedicínského inženýrství v této tradici pokračuje a má navázány úzké pracovní kontakty s firmami Philips Netherlands (Nizozemí), Philips Česká republika, BLOCK, a. s., MIKRO s. r. o., VUP Medical, a. s., MDT-Medical Data Transfer, s. r. o., Touchless Biometric Systems s. r. o., Smart Brain Sale, s. r. o. Dále ústav spolupracuje s akademickými pracovišti, např́íklad s Oftalmologickou klinikou Friedrich-Alexander-University Erlangen (Německo), University of Bergen (Norsko), Ústavem př́strojové 
techniky Akademie věd České republiky, Asociací výrobců a dodavatelů zdravotnických prostředků, Lékařskou fakultou Masarykovy univerzity v Brně, Mendelovou univerzitou, Výzkumným ústavem veterinárního lékařství, Vysokou školou chemicko-technologickou v Praze a klinickými pracovišti, např́ílad s Fakultní nemocnicí Brno a Fakultní nemocnicí u sv. Anny. Výše uvedené instituce se také podílejí na rozvoji výuky ústavu konzultační a přednáškovou činností a dále zajišt'ováním stáží a praxí studentů.

\section{Výzkumná činnost}

Původní výzkumná činnost Katedry lékařské elektroniky bezprostředně souvisela s jejím technickým vybavením. Projevil se zde hlavně celkový stav techniky pro zdravotnictví v tehdejším socialistickém státě. Zlepšování kvality obecného technologického vybavení katedry a také nástup digitální výpočetní techniky změnily možnosti i priority a oblasti výzkumu na katedře. V počátcích se výzkum orientoval např́klad na svodové systémy pro snímání elektrokardiografických signálů, dále na zpracování biologických signálů, později s príichodem číslicové techniky a elektroniky pak na číslicové a počítačové zpracování biologických signálů. Zcela novým oborem se stalo s prríchodem dostupné výpočetní techniky číslicové zpracování obrazi̊, které bylo v rámci Československa zavedeno na katedře jako na prvním akademickém pracovišti. Současné zaměření výzkumu Ústavu biomedicínského inženýrství již doznalo značných změn, a to hlavně v souvislosti se špičkovým technologickým vybavením ústavu a se zaměřením pracovníků ústavu na aktuální světová výzkumná témata. Současné výzkumné aktivity ústavu lze rozdělit do pěti hlavních směrů, které mají historické kořeny či byly etablovány relativně nedávno.

Do oblasti akvizice a zpracování signálů spadá především oblast klinické a experimentální kardiologie, včetně výzkumu prováděného na izolovaných srdcích. Dále pak oblasti získávání signálů v polysomnografiii, včetně záznamu a zpracování EMG a EEG signálů ve specifických aplikacích (biofeedback, měření reakční doby řidičů, hodnocení únavy apod.).

Zpracování obrazů a zobrazování v medicíně a biologii je tradiční oblastí Ústavu biomedicínského inženýrství, která je aktuálně zaměřena na zpracování obrazů z klasických modalit (CT, CT/PET, funkční MRI, ultrazvukové zobrazování, mikroskopie). V posledních několika letech jsou také aplikovány principy fotoniky v různých oblastech, např́klad zobrazování v oftalmologii či optické měření vitálních funkcí.

Výzkum rehabilitačního inženýrství je zaměřen na získávání a analýzu signálů zaznamenávaných během terapie pacientů s postižením pohybového aparátu, ale také během fyzických aktivit při sportovním výkonu.

Buněčná biologie zkoumá především aplikace základních a pokročilých mikroskopických metod pro studium vlastností a interakcí živých buněk a buněčných kultur. Studie jsou zaměřeny především na výzkum v oblasti kardiomyocytů, elektrofyziologie buněk či studium buněčného metabolismu.

Bioinformatika a in-silico návrh léčiv je oblast výzkumu, související s novým zaměřením ÚBMI v oblasti výuky. Jde především o aplikaci inženýrských př́stupů v analýze genomických dat či specifické genomické studie zaměřené např́íklad na rezistence bakterií vůči antibiotikům. Další rozvíjející se oblastí je počítačový návrh léčiv a počítačové modelování proteinů. 
Pracovníci ústavu získali v minulosti i v nedávné době ochranu duševního vlastnictví svých výstupů ve formě řady patentů a užitných vzorů. I to svědčí o tom, že výzkumným aktivitám ústavu a uplatnění jejich výstupů je věnováno velké úsilí.

\section{Vedoucí ústavu}

Prof. Ing. Vratislav Vrána, CSc. (1967 - prosinec 1989) se zasloužil o vznik Katedry lékařské elektroniky na Elektrotechnické fakultě VUT v Brně jako první vzdělávací a výzkumné instituce v oboru biomedicínského inženýrství v tehdejším Československu. Prosadil, aby se nová katedra v rámci Elektrotechnické fakulty stala respektovaným pracovištěm, zejména v těsné spolupráci s Katedrou radioelektroniky a Katedrou linkové techniky. Zavedl zcela nový teoretický předmět živý organismus v elektronických soustavách, v rámci něhož zdůvodnil řadu jevů probíhajících v živém organismu. Podílel se také na výzkumu katedry, hlavně v oblasti systémů pro snímání elektrokardiografických signálů. Za působení profesora Vrány se Katedra lékařské elektroniky postupně rozvíjela, vznikly tři hlavní výzkumné směry (lékařská elektronika, číslicové zpracování medicínských obrazů a číslicové zpracování biologických signálů), které se odrážely i v náplni výuky. Když v roce 1975 vznikla Česká společnost biomedicínského inženýrství, byl profesor Vrána jedním z jejich pěti zakladatelů.

Prof. Ing. Jiří Jan, CSc. (prosinec 1989 - březen 2010) měl významný podíl na dalším rozvoji katedry s využitím nových možností spolupráce se zahraničím, vedl první zahraniční ústavní výzkumný projekt TEMPUS. Založil tradici organizace mezinárodní bienální konference BIOSIGNAL a jako předseda programového výboru navázal kontakty ústavu s významnými zahraničními vědci. V roce 1999 vznikl navazující magisterský obor biomedicínské a ekologické inženýrství, na jehož vzniku a formování struktury měl rozhodující podíl. Ve výzkumu se zabýval především metodami číslicového zpracování a analýzy biomedicínských obrazů, který jako vědní obor na ústav přinesl a rozvíjel. Je autorem řady odborných zahraničních knih zabývajících se touto problematikou.

Prof. Ing. Ivo Provazník, Ph.D. (duben 2010 - doposud) se značně podílel na dalším rozvoji ústavu zejména $\mathrm{v}$ oblasti výukové. Zavedl nové studijní obory, a to bakalářský obor biomedicínská technika a bioinformatika, navazující magisterský obor biomedicínské inženýrství a bioinformatika a doktorský obor biomedicínské technologie a bioinformatika. Zasloužil se o nový rozvoj infrastruktury ústavu (zejména laboratoří a speciálních provozů), která se dostala na světově srovnatelnou úroveň. Na ústavu zavedl nový výzkumný směr bioinformatiky a vytvořil novou výzkumnou skupinu. Aktivně zapojil ústav do společného výzkumu v rámci Mezinárodního centra klinického výzkumu (ICRC) Fakultní nemocnice u sv. Anny v Brně (2011-2015). Navázal také dlouhodobou spolupráci s Fyziologickým ústavem Lékařské fakulty Masarykovy univerzity. Pod jeho vedením se na ústavu dále etablovalo rehabilitační inženýrství.

Doc. Ing. Milan Chmelař, CSc. (pověřený vedoucí ústavu v letech 1967-1968 a 1990-1994) převzal podklady o uzavřených dohodách a přidělenou budovu v době zakládání ústavu, kdy profesor Vrána rok působil na Technical Military College v Káhiře. Měl za úkol uvést 
nově vzniklou katedru do života a zajistit zahájení výuky. To znamenalo zprovoznit budovu, která byla v havarijním stavu, a zařídit laboratoře, což nebylo $v$ tehdejší době plánovaného hospodářství vzhledem $\mathrm{k}$ nedostatku materiálu a ochoty spolupracovat jednoduché. Problémy byly i s externisty pro zajišstění výuky. Podruhé zastupoval tehdejšího vedoucího profesora Jana. Ten se v roce 1990 stal proděkanem pro tvưrčí činnost. Podle tehdejších předpisů nebylo možno současně vykonávat funkci vedoucího ústavu a děkana nebo proděkana.

Dne 1. 2. 2017 to bylo právě padesát let od vzniku samostatné Katedry lékařské elektroniky. Elektrotechnická fakulta VUT v Brně byla v rámci republiky první, která specializovanou Katedru lékařské elektroniky zrrídila. Za léta svého působení významně přispěla $\mathrm{k}$ rozvoji lékařské elektroniky $\mathrm{v}$ naší republice a vychovala celou řadu odborníků. Také se stala vzorem pro ostatní vysoké školy. Postupem času pak došlo v naší republice k rozšíření výuky lékařské elektroniky i na jiných vysokých školách. Vrcholem je samostatná Fakulta biomedicínského inženýrství na Českém vysokém učení technickém.

\section{Bibliografická poznámka}

Od roku 1959 vydávala Elektrotechnická fakulta VUT pro př́slušný studijní rok brožury s názvem Studijní program, které obsahovaly mimo jiné údaje o výuce a výzkumu jednotlivých kateder a rovněž uváděly personální obsazení kateder. Nedochovaly se všechny, jak ukazuje následující seznam. V současnosti tyto brožury již vydávány nejsou, informace o výuce je možno nalézt na webových stránkách jednotlivých ústavů.

\section{Studijní programy:}

Archiv VUT v Brně (AVUT), fond Rektorát vysokého učení technického Brno, roky 1959/1960, 1961/1962-1971/1972;

Studijní oddělení FEKT VUT v Brně, roky: 1974/1975-1976/1977, 1979/1980-1983/1984, 1985/1986-1986/1987.

Dále byla použita korespondence fakulty, uložená v archivu VUT, fond Fakulta elektrotechnická Vysokého učení technického Brno, korespondence Biomedicínské inženýrství, č. j. 22360/90 ze dne 14. 5. 1990 - dopis z Katedry lékařské elektroniky děkanovi FE; č. j. 25092/00 ze dne 12. 6. 2000 - dopis ministra školství děkanovi FE; č. j. 304/4911/02 ze dne 29. 8. 2002 - dopis děkana FE na Ministerstvo školství; č. j. 48095/2006 ze dne 22. 11. 2006 - př́ípis z Ministerstva školství děkanovi FE.

Někde jsem informace doplnil i z vlastních vzpomínek, protože jsem na Katedře lékařské elektroniky, respektive Ústavu biomedicínského inženýrství pracoval od jejího počátku až do současnosti.

Informace o aktuální spolupráci ústavu s institucemi a podniky poskytl nynější vedoucí ústavu prof. Ing. Ivo Provazník, Ph.D. Informace o současných výzkumných aktivitách poskytl doc. Ing. Radim Koláŕ, Ph.D. Informace o současných studijních oborech byly prevzzaty z webové stránky ústavu: www.dbme.feec.vutbr.cz. 


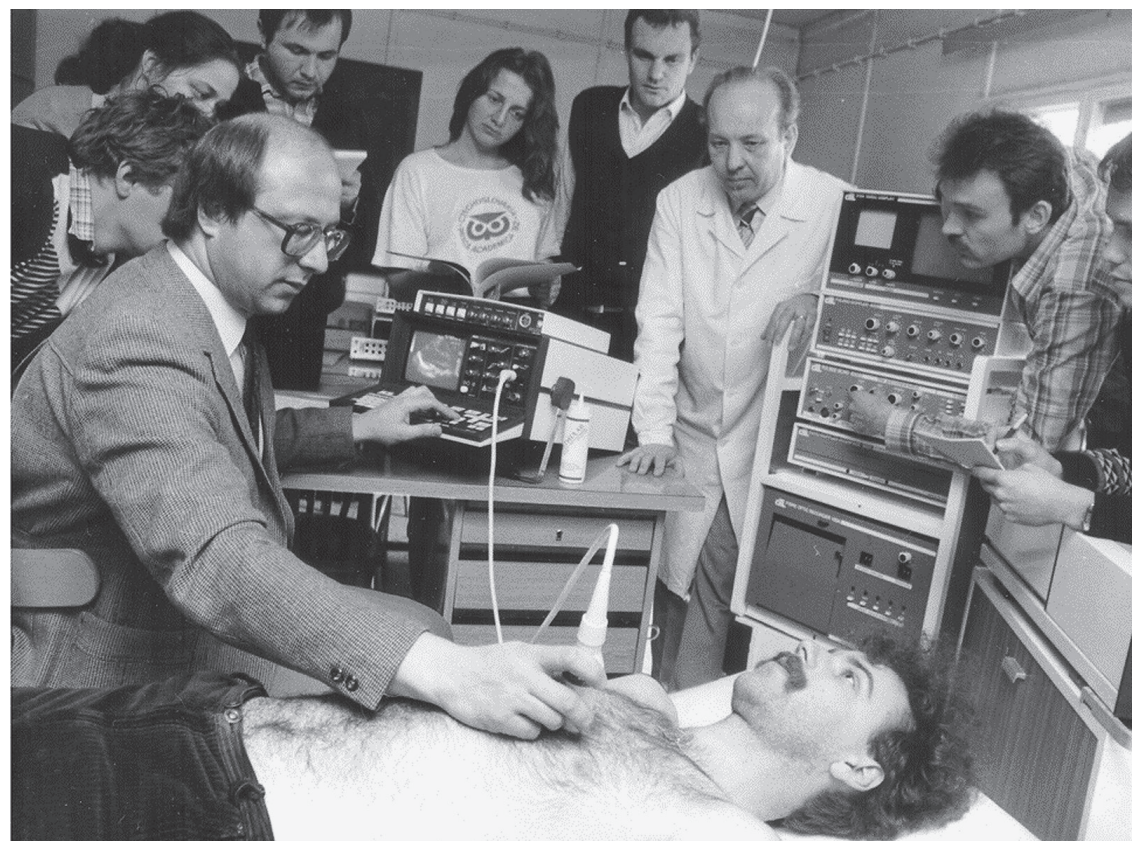

Obr. 1 Laboratorní cvičení - Tesco barák Purkyňova 95b

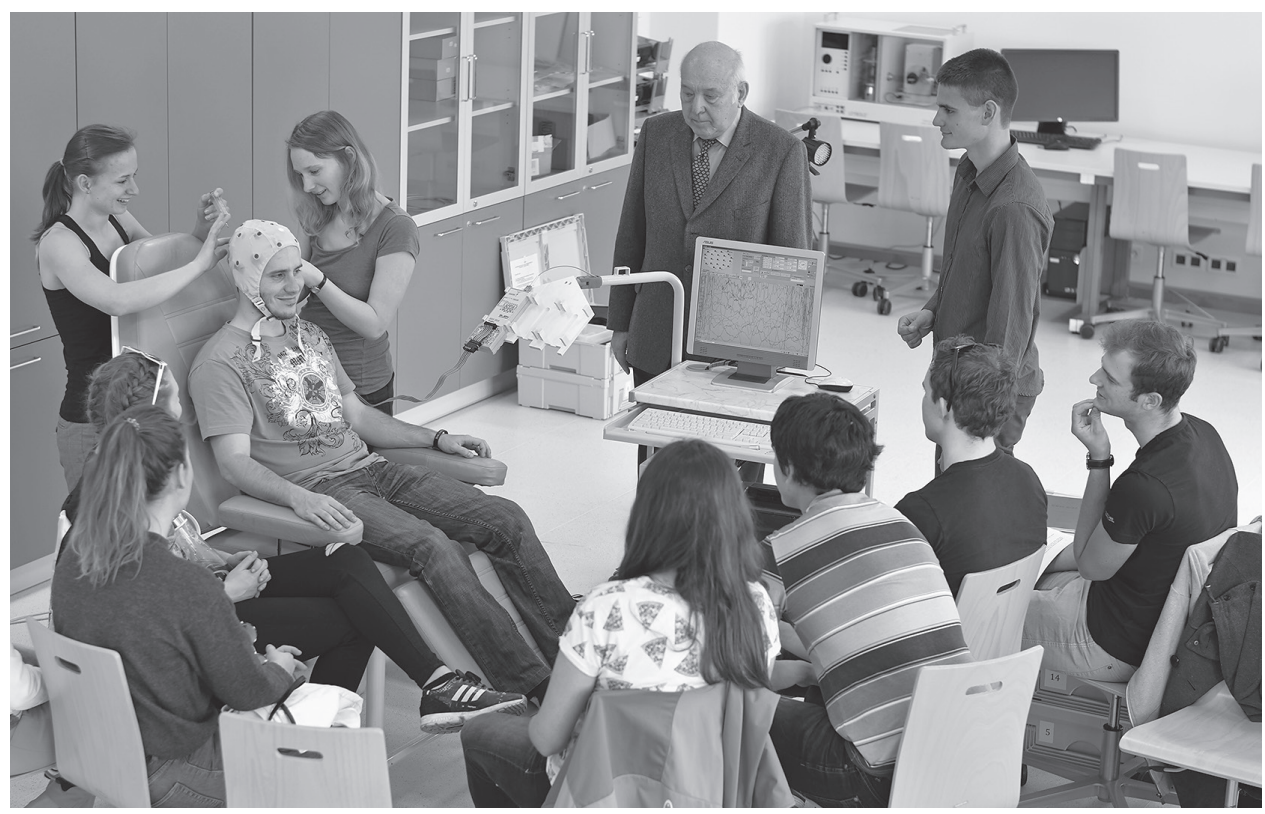

Obr. 2 Laboratorní cvičení - snímaní EEG - Budova FEKT VUT Technická 12 


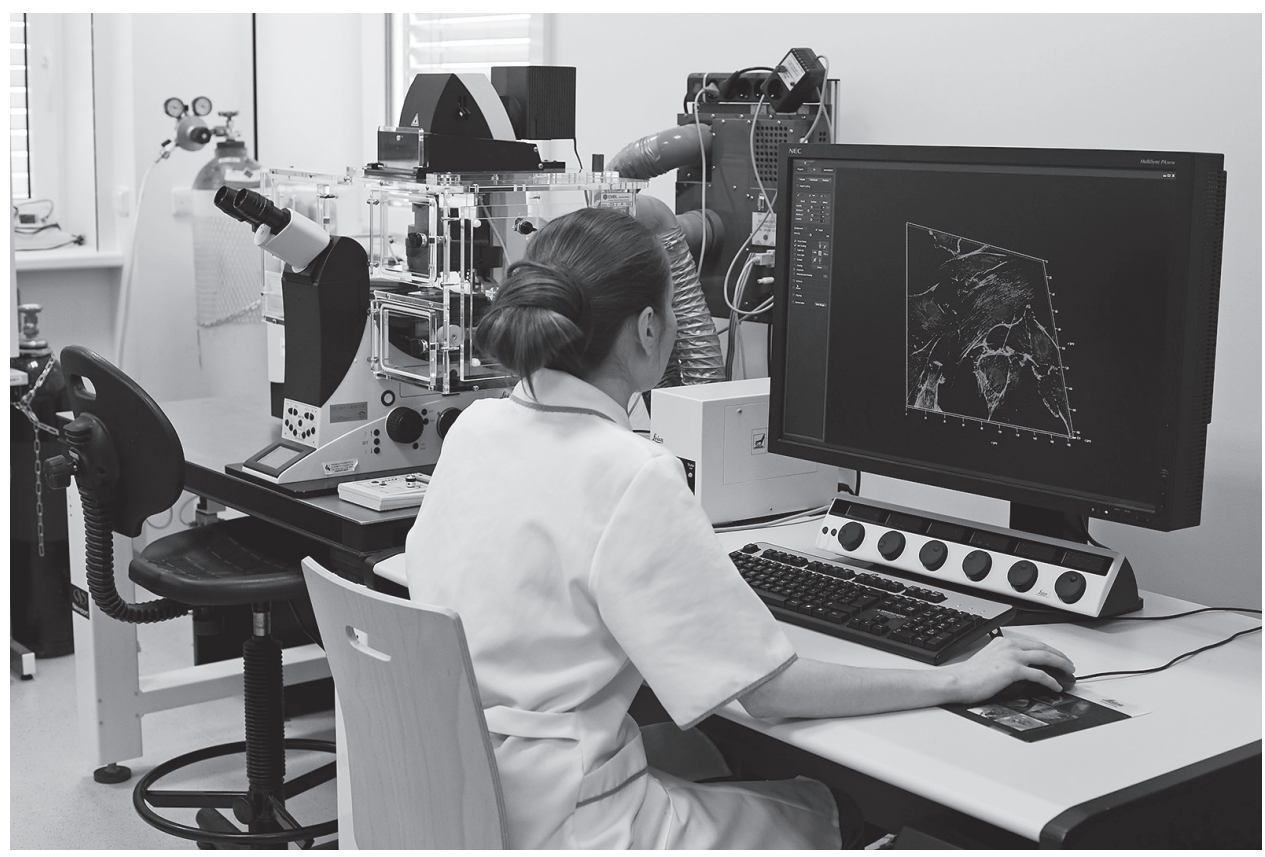

Obr. 3 Jedna z výzkumných laboratoří ústavu - budova FEKT VUT, Technická 12

\author{
MILAN CHMELǍ̆
}

\title{
Geschichte der Medizinelektronik als Unterrichtsfach an der Elektrotechnischen Fakultät der Technischen Hochschule in Brünn (Brno)
}

\section{ZUSAMMENFASSUNG}

Der Lehrstuhl Medizinelektronik der Elektrotechnischen Fakultät der Technischen Hochschule Brünn war der erste selbstständige Lehrstuhl seiner Art in der Tschechoslowakei. Errichtet 1967, trug er auf bedeutende Weise zur Entwicklung der Medizinelektronik bei und brachte eine ganze Reihe von Fachleuten hervor. Der Beitrag verfolgt die Geschichte des Faches Medizinelektronik, insbesondere die Entwicklung besagten Lehrstuhls, der 1990 in den Lehrstuhl für biomedizinisches Ingenieurwesen und später in das gleichnamige Institut umbenannt wurde. Skizziert werden auch die Zusammenarbeit dieser Hochschuleinrichtung mit der Industrie und dem Gesundheitswesen sowie die Forschung der Institutsmitarbeiter. Dem Beitrag beigegeben sind kurze Charakteristiken der Institutsleiter von 1967 bis zur Gegenwart.

Milan Chmelar̆

Ústav biomedicinského inženýrství

Fakulta elektrotechniky a komunikačnich technologií

Vysokého učeni technického $v$ Brně

chmelar@feec.vutbr.cz 